МИРОСЛАВ КРИШТАНОВИЧ, доктор наук з державного управління, професор, професор кафедри педагогіки та інновачійної освіти, Інститут права, психології та інноваційної освіти Наџіонального університету

"Львівська політехніка", Україна ORCID ID: 0000-0003-1750-6385 mf0077@ukr.net

СВІТЛАНА КРИШТАНОВИЧ, кандидат наук з державного управління, дочент, дочент кафедри економіки та менеджменту, Львівський державний університет фізичної культури імені Івана Боберського, Украӥна ORCID ID: 0000-0002-2147-9028 skrischtanovich@gmail.com

\title{
ОСОБЛИВОСТІ ФОРМУВАННЯ ПРОФЕСІЙНО-ПЕДАГОГІЧНОӤ КОМПЕТЕНТНОСТІ ВИКЛАДАЧА ЗАКЛАДУ ВИЩОЇ ОСВІТИ У ПРОВІДНИХ КРАЇНАХ ЄВРОПИ
}

\author{
MYROSLAV KRYSHTANOVYCH, Doctor of Science in Public \\ Administration, Professor, Professor of the Department of Pedagogy \\ and Innovative Education, Institute of Law, Psychology and Innovative \\ Education National University "Lviv Polytechnic", Ukraine \\ SVITLANA KRYSHTANOVYCH, Candidate of Sciences in Public \\ Administration, Associate Professor, Associate Professor of the \\ epartment of Economics and Management State University of Physical \\ Culture named after Ivan Bobersky, Ukraine
}

\section{PECULIARITIES OF FORMATION OF PROFESSIONAL AND PEDAGOGICAL COMPETENCE OF THE TEACHER OF THE HIGHER EDUCATION INSTITUTION IN THE LEADING COUNTRIES OF EUROPE}

У статті акцентується на особливій актуальності питання розвитку професійно-педагогічної компетентності викладачів закладів вищої освіти; наголошується на необхідності використання зарубіжного досвіду у сфері педагогічної діяльності.

Проаналізовано процес освітньої підготовки і підвищення професійної компетентності викладачів, аргументовано доведено, що це залежить від особливостей соціально-економічного і політичного життя, історичних традицій, національного менталітету, педагогічних напрацювань кожної з розвинених країн. Автором зроблений висновок, що лише за наявності високого рівня професійно-педагогічної компетентності майбутній викладач закладу вищої освіти зможе отримати таке звання, яке забезпечуватиме йому право проводити заняття уЗВО.

(C) М. Криштанович, С. Криштанович
Ключові слова: студент, викладач, заклад вищої освіти, професійно-педагогічна компетентність, країни Європейського Союзу.

Summary. Currently, education systems in different countries are experiencing trends in the standardization of the educational process related to globalization processes, and at the same time there is an increasing need to improve the level of teacher training for HSE. Therefore, the issue of developing their professional and pedagogical competence is of particular relevance.

Achieving an adequate level of professional and pedagogical competence of Ukrainian teachers of HEA in modern conditions requires the use of foreign experience in the field of pedagogical activity. This requires indepth and comprehensive analysis and dissemination of good practice and new educational strategies in the world community.
The study of this experience opens new opportunities for improvement of the process of professional and pedagogical competence of teachers of the HSE of Ukraine. In this context, the progressive achievements of countries demonstrating high levels of teachers' professional and pedagogical competence, in accordance with world standards that have rich historical traditions of education, have accumulated considerable experience in the field of teacher retraining in the new sociocultural context.

We have analyzed the process of educational training and professional development of teachers and argued that it depended on the characteristics of socio-economic and political life, historical traditions, national mentality, pedagogical traditions of each of the developed countries.

Thus, only in the presence of a high level of professional and pedagogical competence did the future teacher of the 
institution of higher education be able to obtain the title that gave him the right to take classes in the HSE.

Our analysis of this experience will undoubtedly help to increase the required level of professional and pedagogical competence of higher education teachers of Ukraine.

Key words: student, teacher, institution of higher education, professional and pedagogical competence, European Union countries.

Мета: вивчити та проаналізувати стан професійно-педагогічної компетентності викладача закладу вищої освіти у провідних країнах Свропи.

Постановка проблеми в загальному вигляді. Слід зазначити, що в західноєвропейських державах головною вимогою до рівня розвитку професійно-педагогічної компетентності викладача закладу вищої освіти (далі 3ВО) неабияка увага приділяється таким якостям, як уміння самостійно знаходити шляхи розв'язання комплексних завдань, здобувати нові знання, набувати навичок, мати позитивну уявупро власну особистість; здатність спілкуватись зі студентами, комфортно поводитися в колективі.

Експерти країн Європейського Союзу професійно-педагогічну компетентність викладача визначали, насамперед, як "здатність застосовувати знання й уміння", що сприяє активному застосуванню навчальних досягнень у нових ситуаціях.

Грунтовну дискусію навколо того, як озброїти викладача ЗВО необхідними вміннями та знаннями для забезпечення достатнього й належного рівня його професійно-педагогічної компетентності, сьогодні ведуть більшість європейських країн. Саме тому вони вважають, що у цьому процесі важливим є усвідомлення суті даної компетентності в педагогічній науці і практиці. Необхідно було визначити, у якому напрямі ії розвивати (компетентність), щоб вона могла стати основним критерієм для роботи у 3ВО. Тому так важливо враховувати педагогічні здібності викладача ЗВО, його індивідуально-психологічні особливості, рівень застосування набутого педагогічного досвіду тощо.

Аналіз досліджень і публікацій. Зарубіжні науковці, такі як Ж. Вінтертон, Ф. Деламар-ЛеДейст, Е. Стрінгфеллоу, Дж. Равен, Л. Холм і D. McClelland, E. Карветі, досліджували питання ролі та рівня професійно-педагогічної компетентності викладачів уроботі закладу вищої освіти. У своїх працях вони справедливо наголошували, що серед основних професійнопедагогічна компетентність найбільш важлива, оскільки безпосередньо пов'язана 3 виконанням професійних обов'язків.

Виклад основного матеріалу дослідження. У 2005 році Свропейським парламентом оприлюднено рекомендації щодо визначення головних компетенцій, ут. ч. і професійно-педагогічної, які дозволятимуть особі усвідомлювати та використовувати можливості для саморозвитку, визначення цілей та стратегій якісної освіти, а також відповідно і способів навчання (Karweti, 2014). Дана компетенція обумовлювалась сформованістю умінь викладача планувати, організовувати діяльність, управляти ії ходом, аналізувати та прогнозувати отримані результати, оцінювати ризики і власні ресурси. Рівні сформованості зазначеної компетенції мають виявлятися у здатності викладача співвідносити власні творчі здібності з можливістю іiі виявлення на певному професійному рівні.

Слід зазначити, що в основу європейських підходів до професійно-педагогічної компетентності викладачів 3ВО покладена так звана дублінська модель універсальних описів компетенцій (дублінські дескриптори): знання і розуміння; застосування знань i розумінь; формулювання суджень; комунікації; бажання і здатність до підвищення кваліфікації (Голубенко, 2007).

Так, згідно з Свропейською системою кваліфікацій сучасному викладачеві необхідно:

- використовувати спеціальні знання щодо критичного аналізу, оцінки та синтезу нових складних ідей на основному рубежі відповідної галузі, розширювати або переосмислювати набуті знання і професійну практику в рамках конкретної галузі або на стику галузей;

• уміти досліджувати, розробляти, реалізовувати й адаптувати проєкти, що ведуть до здобуття нового знання і нових рішень;

- демонструвати значні лідерські якості, інноваційність і самостійність у трудовій та навчальній діяльності в нових контекстах, що вимагають вирішення проблем, які витікають 3 безлічі взаємозв'язаних чинників;

- демонструвати здатність підтримувати стійкий інтерес до розробки нових ідей або процесів, високий рівень розуміння процесів навчання;

- авторитетно спілкуватися в рамках критичного діалогу з рівними за статусом фахівцями;

- вивчати й розмірковувати над соціальними нормами, взаєминами і бути лідером змін;

- критично аналізувати, оцінювати, синтезувати нові і складні ідеї, приймати стратегічні рішення, виходячи 3 цих процесів;

- демонструвати досвід операційної взаємодії зі здатністю ухвалення стратегічних рішень у складному оточенні (International Standard Classification of Education, 1997).

Головне питання, яке вирішувалось у цьому напрямі, - характеристика елементів діяльності викладачів, їх виконання для задоволення освітніх потреб ЗВО, належного прояву професійно-педагогічної компетентності.

Заслуговує на увагу те, що критеріями розвитку професійно-педагогічної компетентності викладача, необхідними для роботи у ЗВО, визначені наступні: мотиваційно-ціннісний, який виявляється через сукупність мотивів і потреб, що спонукають педагога до розвитку необхідної професійно-педагогічної компетентності; когнітивний, що характеризується системою набутих знань, якими має володіти викладач 3ВО; практичний, який забезпечується шляхом реалізації сформованих відповідних професійних умінь і навичок.

Сучасні вимоги до педагогічних кадрів ЗВО у Франції передбачають більш сконцентрований підхід до розвиткуїх професійно-педагогічної компетентності. Це, насамперед, уміння: використовувати дискусії у навчальному процесі, реалізація завдань комунікативно-діалогічного характеру, виконувати експериментальні вправи, аналізувати й вирішувати незаплановані педагогічні ситуації. Для цього викладач повинен широко застосовувати "проблемні методи", методи демонстрації педагогічних відеофільмів, моделювання, мікровикладання, рольові ігри, презентації проєктів тощо (Лащчихіна, 2009).

Система підвищення професійнопедагогічної компетентності викладачів ЗВО в Німеччині передбачає курси підвищення кваліфікації, семінари, конференції. До їх проведення висуваються певні вимоги: заняття мають бути короткотерміновими; вони повинні проходити недалеко від місця проживання і праці викладачів; на них виносяться проблеми, які особ- 
ливо актуальні для закладу, у якому працює викладач; зміст занять має плануватися з урахуванням побажань самих слухачів і допомагати їм долати труднощі, що мають місце у практичній діяльності.

Кожна з названих вище форм роботи має свої особливості і переваги. Так, наприклад, педнаради у вишах Німеччини як один з напрямів підвищення професійно-педагогічної компетентності проводяться тоді, коли виникає потреба ознайомити педагогів 3 державними документами в галузі освіти, директивами стосовно змін у навчальних програмах, обговорити нові технології навчання. Відвідування занять членами педагогічного колективу найчастіше практикуються у випадку, коли виникає потреба оцінити нововведення у галузі методики навчання чи надати конкретну допомогу у проблемній чи конфліктній ситуації, що виникла у працівника (Die besten Hochschulen in Deutschland, 2001).

У процесі розвитку професійнопедагогічної компетентності викладачів 3ВО Німеччини загальновизнаними вимогами щодо рівня їх освіти $\epsilon$ дотримання тенденції міждисциплінарності та максимально можливе узгодження нормативних і варіативних курсів. Про це свідчить практика організації роботи щодо підвищення їх кваліфікації, зокрема, у Гамбурзькому, Гейдельберзькому, Гетингензькому, Оснабрукському та Рурському університетах (Чулкова, 2006). У кожномуз них залежно від локальних умов, наукових, суспільних чинників визначають рівень необхідної освітньої підготовки викладачів, аргументують доцільність упровадження нормативних і варіативних курсів для їх перепідготовки, інтегрованих програм, перспективних методик навчання у післядипломній освіті тощо. Для цього використовуються такі інноваційні методи навчання: рольові та ділові ігри, метод проєктів, тренінги, "ментальні карти", кейс-метод, мозковий штурм, моделювання ситуацій, презентації тощо. Усі вони мають позитивний вплив на підвищення рівня професійно-педагогічної компетентності викладачів для роботи у ЗВО (Bauer, 2006).

Аналіз спеціальної літератури свідчить про те, що розвиток професійно-педагогічної компетентності викладачів ЗВО Німеччини відбувається завдяки створенню в окремих закладах належних організаційно-педагогі- чних умов, які дозволяють ефективно досягати мети з урахуванням специфіки та особливостей їх професійної діяльності.

Система професійної перепідготовки викладачів 3ВО на основі формування в них професійно-педагогічної компетентності в таких європейських державах, як Польща, Литва, Угорщина, здійснювалась на основі післядипломних технологій з багатопрофільними мережами додаткового навчання, що функціонують і на базі спеціально визначених навчальних закладів, а також у формі підвищення кваліфікації безпосередньо на місцях педагогічної діяльності з онлайн-доступом $з$ допомогою чітко окреслених навчальних програм. На думку польських учених, у процесі розвитку професійно-педагогічної компетентності викладачів ЗВО провідними залишаються принципи: безперервності, єдності і диференціації, заміни вузькопрофільного навчання широкопрофільним, усебічного розвитку за широкого діапазону освіти, гнучкості, науковості й економічності освіти.

У Стратегії розвитку освіти Польщі на 2007-2013 роки закладені основні принципи і тенденції формування професійно-педагогічної компетентності викладачів ЗВО, що набуває значущості у процесі розвитку гнучкої освітньої системи, здатної адаптуватися до змін, пов'язаних з прогресом у науці, новими технологіями та глобалізацією, а також позитивними змінами в міжнародному освітньому просторі, що пояснюється реалізацією прозорої системи професійних кваліфікацій; створенням єдиної системи для визнання професійних кваліфікацій викладачів (Пальчук, 2011).

Таким чином, професійно-педагогічну компетентність викладача 3ВО вважаємо основною у процесі його перепідготовки з усього курсу дисциплін, необхідних для вміння будувати навчальний процес жваво, емоційно, цікаво; відбирати зміст і відповідне обладнання для проведення навчального заняття; викладати навчальний матеріал доступно, чітко, виразно, переконливо; розробляти необхідний дидактичний матеріал для академічного заняття зі студентами.

Отож здійснене вивчення провідного європейського досвіду щодо формування професійно-педагогічної компетентності викладачів для сфери вищої освіти засвідчив наявність:

- чіткої спрямованості державної політики провідних європейських країн на розвиток необхідного потенціалу викладачів 3ВО;

- нормативно-правового підгрунтя для забезпечення підтримки, а також інтегрованості їх професійного розвитку;

- обгрунтованих орієнтирів і результатів реалізації програм професійної перепідготовки для роботи у 3BO.

Так, в Англії увага зосереджувалась не на особистісних характеристиках, а на властивостях самої діяльності викладача (Oja, 2009). Головне питання, що розв'язувалось у цьому напрямі, спрямовувалось на головні елементи в діяльності викладачів для задоволення заданих освітніх вимог.

Оскільки діяльність викладацького складу регламентується професійними стандартами, в Англії Академією вищої освіти спільно з університетами затверджено Національну рамку професійних стандартів для викладачів вищої освіти (2011), яка включає три виміри якісного формування їх професійно-педагогічної компетентності: сфера діяльності, основні знання, професійні цінності з відповідними дескрипторами. До професійних цінностей віднесено: повагу до кожного студента; сприяння йому уздобутті вищої освіти; використання фактичних даних результатів досліджень 3 викладання та постійний професійний розвиток; розуміння ним контексту вищої освіти, застосування професійної практики (Медведовська, 2016).

Останнім часом у підвищенні рівня професійно-педагогічної компетентності викладача ЗВО спостерігається процес активного впровадження моделі онлайнового навчання (online learning), що передбачає широке застосування локальних і глобальних комп'ютерних мереж у структурі Британського Відкритого університету (Чорна, 2010). Інтерактивний контакт у режимі онлайн дає можливість викладачу швидко надіслати запитання та отримати необхідну консультацію. Виділяють три типи курсів підвищення рівня професійно-педагогічної компетентності викладачів, що базуються на активному використанні інформаційно-комунікаційних технологій (далі - IКТ): веб-інтенсивні (Webintensive) - навчальний процес повністю відбувається в онлайновому режимі; веб-фокусовані (Webfocused) - передбачається використання ITК як обов'язкового елемента необхідної навчальної програми щодо 
підвищення кваліфікації; веб-підсилені (Web-enhanced) - забезпечуються можливістю вільного доступу до електронних послуг, що дозволяє викладачу не обов'язково знаходитися в режимі онлайн.

Така схема склалася і в інших 3 ВО Англії у ході тривалого історичного розвитку і на сьогодні залишається однією 3 найпопулярніших форм підвищення кваліфікаційного рівня викладачів, формування їх професійно-педагогічної компетентності.

На сучасному етапі в такій країні як Данія, також спостерігається серед науковців активний пошук нових моделей формування професійно-педагогічної компетентності, що направлена на розроблення вимог, які сприяли б ефективному вирішенню цієї проблеми шляхом поглиблення зв'язку теорії і практики у процесі професійної діяльності викладача. Головними вимогами до їх педагогічної діяльності і розвитку цієї компетентності визначено: поглиблення професійного мислення з акцентом на педагогічнурефлексію, самоаналіз, гармонійне поєднання критичного та творчого осмислення принципів ефективної діяльності у ЗВО, які дають можливість вийти з будь-якої педагогічної ситуації, миттєво знайти правильне рішення (Роляк, 2010).

Висновки та перспективи подальших досліджень. Таким чином, на основі проведеного теоретичного аналізу зарубіжного досвіду щодо розвитку професійно-педагогічної компетентності викладачів для їх роботи в системі вищої освіти можна виокремити основні аспекти реалізації означеної проблеми, а саме:

- обов'язковий зв'язок стандартів педагогічної підготовки спеціалістів зі стандартами, які визначені в нормативно-правових нормах здійснення освітнього процесу у 3ВО;

- вибір необхідних навчальних дисциплін, які мають бути пов'язані з педагогічною діяльністю, зважаючи на необхідні питання педагогіки і дидактики.

Професійно-педагогічну компетентність викладача слід розуміти як наявність у нього не стільки значного обсягузнань і досвіду, скільки вмінь актуалізувати накопичені знання і вміння, у потрібний момент їх використовувати у процесі реалізації своїх професійних функцій узакладі вищої освіти.
Вивчення зарубіжного досвіду, на наш погляд, $\epsilon$ важливим, але при цьому існує потреба теоретичного обгрунтування та експериментальної перевірки перспективної моделі розвитку професійно-педагогічної компетентності викладачів закладів вищої освіти країн Європейського Союзу.

\section{СПИСОК ЛТТЕРАТУРИ}

Karweti, E. (2014). Influence managerial ability of principals and factors affecting the motivation work on the performance of special-ed teacher. Journal Educational Research, Vol. 11, 2,21-31.

Голубенко, О., Морозова, Т. (2007). Європейська мета структури кваліфікацій для сфери освіти. Вища школа, 2, 35-39.

International Standard Classification of Education. (1997). (Reedition). Retrieved from www.uis.unesco.org/ Library/Pages/ DocumentMoreP age.aspx?docIdValue.

Лащихіна, В. П. (2009). Розвиток системи підготовки педагогічних кадрів уФранції (друга половина XX - початок XXI століття). (Дис. канд. пед. наук). Київський національний лінгвістичний університет, Київ.

Die besten Hochschulen in Deutschland. (2001). Stern, Heft , 17, 57-68.

Чулкова, Л. О. (2006). Проблемы работы преродавателя в ВНЗ Германии. Бердянск : Модем.

Bauer, K.-O., Kopka, A., Brindt, S. (2006). Padagogische Professionalitat und Lehrerarbeit. Weinheim und Munchen.

Пальчук, М. (2011). Модель професійної освіти і навчання у Польщі четвертий етап європейської інтеграції. Порівняльна професійна педагогіка, 2, 101-111.

Oja, S. N. (2009). Perspectives on Teacher Professional Development. London.

Медведовська, Д. (2016). Основні критерії якості вищої освіти: досвід Великобританії. Педагогічні науки: теорія, історія, інновачійні технології, 4 (58), 48-54.

Чорна, О. (2010). Сучасні тенденції підготовки та підвищення кваліфікації викладачів ВНЗ (на прикладі відповідного досвіду Великої Британії). Наукові записки, 88, 273-276.

Роляк, А. О. (2010). Підготовка вчи- теля в Данії. Кам'янець-Подільський : ФОП Сисин О. В.

\section{REFERENCES}

Karweti, E. (2014). Influence managerial ability of principals and factors affecting the motivation work on the performance of special-ed teacher. Journal Educational Research, 11, 2, 21-31.

Holubenko, O., Morozova, T. (2007). Yevropeyska meta struktury kvalifikatsiy dlya sfery osvity. Vyshcha shkola, 2, 35-39.

International Standard Classification of Education (1997). (Reedition). Retrieved from www.uis.unesco.org/ Library/Pages/ DocumentMoreP age.aspx?docIdValue.

Lashchykhina,V. P. (2009). Rozvytok systemy pidhotovky pedahohichnykh kadriv u Frantsiyi (druha polovyna XX pochatok XXI stolittya). (Dys. kand. ped. nauk). Kyivskyy nats. linhvistychnyy unt, Kyiv.

Die besten Hochschulen in Deutschland, (2001). Stern, Heft, 17, 57-68.

Chulkova, L. O. (2006). Problems of work of the transducer in German universities. Berdyansk : Modem.

Bauer, K.-O., Kopka, A., Brindt, S. (2006). Padagogische Professionalitat und Lehrerarbeit. Weinheim und Munchen.

Palchuk, M. (2011). Model profesiynoyi osvity i navchannya $\mathrm{u}$ Polshchi - chetvertyy etap yevropeyskoyi intehratsiyi. Porivnyalna profesiyna pedahohika, 2, 101-111.

Oja, S. N. (2009). Perspectives on Teacher Professional Development. London, 119-154.

Medvedovska, D. (2016). Osnovni kryteriyi yakosti vyshchoyi osvity: dosvid Velykobrytaniyi. Pedahohichni nauky: teoriya, istoriya, innovatsiyni tekhnolohiyi, 4(58), 48-54.

Chorna, O. (2010). Suchasni tendentsiyi pidhotovky ta pidvyshchennya kvalifikatsiyi vykladachiv VNZ (na prykladi vidpovidnoho dosvidu Velykoyi Brytaniyi). Naukovizapysky, 88, 273-276.

Rolyak, A. O. (2010). Pidhotovka vchytelya v Daniyi. KamyanetsPodilskyy : FOP Sysyn O. V.

Стаття надійшла 12.04 .2020 р. 